\title{
Parasites in sympatric populations of native and invasive freshwater bivalves
}

\author{
Jouni Taskinen (i) Maria Urbańska • Fabio Ercoli • Wojciech Andrzejewski • \\ Małgorzata Ożgo • Binglin Deng • Jocelyn M. Choo $\cdot$ Nicoletta Riccardi
}

Received: 5 October 2019/Revised: 22 April 2020/Accepted: 30 April 2020/Published online: 15 May 2020

(C) The Author(s) 2020

\begin{abstract}
An increasing threat to local, native freshwater mussels (Unionida)—an ecologically important but globally alarmingly declining groupis the invasion by exotic bivalves. The Enemy Release Hypothesis predicts that introduced species should benefit from enemy-mediated competition because they are less likely to be harmed by natural enemies, such as parasites, than their native competitors. We investigated within-site differences in parasitism between sympatric native (tot. five spp.) and invasive
\end{abstract}

Guest editors: Manuel P. M. Lopes-Lima, Nicoletta Riccardi, Maria Urbańska \& Ronaldo G. Sousa / Biology and Conservation of Freshwater Molluscs

Electronic supplementary material The online version of this article (doi:https://doi.org/10.1007/s10750-020-04284-0) contains supplementary material, which is available to authorized users.

J. Taskinen $(\bowtie) \cdot$ F. Ercoli · B. Deng · J. M. Choo Department of Biological and Environmental Science, University of Jyväskylä, P.O. Box 35, 40014 University of Jyväskylä, Finland e-mail: jouni.k.taskinen@jyu.fi

M. Urbańska · W. Andrzejewski Institute of Zoology, Poznań University of Life Sciences, ul. Wojska Polskiego 28, 60-637 Poznań, Poland

F. Ercoli

Chair of Hydrobiology and Fishery, Institute of Agricultural and Environmental Sciences, Estonian University of Life Sciences, Kreutswaldi 5, 51006 Tartu, Estonia (tot. three spp.) bivalves in eight northern European waterbodies, which harboured totally 15 parasite taxa. In paired comparisons using within-site averages, the mean number of parasite species in the native bivalves was 2.3 times higher, and the sum of parasite prevalences 2.4 times higher, than in the invasive bivalves. This may lead to enemy-mediated competitive release of invaders and contribute to the success of invasive freshwater bivalves, in general. However, while the invasive clam Corbicula fluminea was completely free from parasites, parasite parameters of the other invader, Sinanodonta woodiana, were relatively high, indicating that the role of parasites can be invader-specific and urges further research. Understanding the factors affecting success of freshwater bivalve invasions, such as parasitism, can aid invasion

\author{
M. Ożgo \\ Department of Evolutionary Biology, Kazimierz Wielki \\ University, Ossolińskich 12, 85-093 Bydgoszcz, Poland \\ N. Riccardi \\ CNR Institute of Water Research, Largo Tonolli 50, \\ 28922 Verbania, Pallanza, Italy
}


control and conservation of local, native (endangered) bivalves.

Keywords Enemy release - Exotic species . Freshwater mussels · Introduced alien species · Nonindigenous species Parasite benefit

\section{Introduction}

Biological invasions threaten biodiversity and cause drastic changes in the invaded ecosystems, leading to local extirpation of native species, biogenic homogenization and extensive economic costs (e.g. Olden et al., 2004; Pimentel et al., 2005; Keller et al., 2011; Lockwood et al., 2013). The most supported explanation (see e.g. Blakeslee et al., 2013) for the success of invasive species (when they have colonized the new, invaded area) is provided by the Enemy Release Hypothesis that invaders benefit from lower pressure of natural enemies when compared to native species (Elton, 1958). Rationale behind the Enemy Release Hypothesis is that (1) natural enemies are harmful and can control populations of their host/target species, and that (2) natural enemies, such as parasites, frequently are specialized to utilize only a small number of host/target species, or even genotypes that are available in their local environment. Therefore, as (3) invaders usually do not bring their own enemies with them to the new area during the colonization process, it (4) results in a situation where the pressure by the natural enemies in the invaded area can be remarkably lower for the invaders than for the local, native species (as well as when compared to the parasite pressure of the invader in its original range). Since parasites and disease are able to control and regulate host populations (Anderson and May, 1979; May and Anderson, 1979; Hudson et al., 1998) and can be highly specialized (i.e., host specific) (Price, 1980), they provide a promising 'enemy candidate'. Two extensive meta-analyses clearly show that the invaders (a) lose their own, natural parasites and pathogens when introduced to a new geographic area, and (b) that their colonization by new parasites in the introduced area does not make up that loss (Mitchell and Power, 2003; Torchin et al., 2003). The introduced animal populations were less heavily parasitized and had only half of the parasite species as compared to their original, natural range (Torchin et al., 2003). In line with this, the invasive plant species which were more completely released from pathogens were more widely reported as harmful invaders (Mitchell and Power, 2003).

Many freshwater mussels (Unionoida) have declined dramatically, so that they are the most imperiled animal group in the world (Lydeard et al., 2004; Lopes-Lima et al., 2017). Invasive bivalves can remarkably harm the native mussels (Haag et al., 1993; Ferreira-Rodriguez et al., 2018), either directly_biofouling by e.g. zebra mussel Dreissena polymorpha (Pallas, 1771)—or indirectly via competition over food, space or host fish or by changing the bottom habitat (Sousa et al., 2014; Ożgo et al., 2020). Therefore, the introduction of invasive bivalves is a serious and increasing threat to local, native bivalves, as non-indigenous bivalve species expand their range at increasing pace (Sousa et al., 2014). In addition, when considering ecosystem functions, some freshwater bivalves can be ranked among the world's most problematic biological invaders. For example, recent invasions of the zebra mussel $D$. polymorpha and Asian clam Corbicula fluminea (Müller, 1774) have altered entire aquatic ecosystems by their filtration and burrowing activities, and they have severely affected native bivalve communities by altering bottom habitats and competing for resources (Karatayev et al., 1997; Strayer et al., 1998; Ward and Ricciardi, 2007; Sousa et al., 2009; Higgins and Vander Zanden, 2010; Ferreira-Rodriguez et al., 2018; Modesto et al., 2019).

Successful establishment and further population growth of introduced freshwater bivalves has been linked, for example to fouling (D. polymorpha prefers shells of unionids over conspecifics), induction of cross-resistance (infection with glochidia of the Chinese pond mussel Sinanodonta woodiana (Lea, 1834) early in the season creates acquired immunity against native unionids in host fishes), potentially longer breeding season, high fecundity and a wide spectrum of suitable fish hosts ( $S$. woodiana), as well as freeliving instead of parasitic larva (D. polymorpha, $C$. fluminea) (Douda et al., 2012; Sousa et al., 2014; Yanovych 2015; Donrovich et al., 2016; DzierżyńskaBiałończyk et al., 2018; Labecka and Domagała, 2018; Urbańska et al., 2018, 2019). However, the role of parasites in success of bivalve invasions has not been thoroughly explored. This is surprising, considering that freshwater bivalves harbor a rich community of 
parasites (Molloy et al., 1997; Grizzle and Brunner, 2009; Carella et al., 2016; Brian and Aldridge, 2019). Indeed, parasitism was recently named as one of the priority research topics on freshwater mussel conservation assessment (Ferreira-Rodríguez et al., 2019). Some of these parasites are capable of markedly reducing the reproductive output, growth and survival of the bivalve host (Taskinen and Valtonen, 1995; Taskinen, 1998b; Jokela et al., 2005; Müller et al., 2014). In addition, parasites of freshwater bivalves can be host specific and adapted to their local host population (Taskinen et al., 1991; Saarinen and Taskinen, 2005), a prerequisite of the Enemy Release Hypothesis. Thus, if occurring at a higher rate in the native bivalves than in the invasive competitors, parasites could benefit the invaders. Parasitism of invasive bivalves has been studied in the invaded areas (e.g. Molloy et al., 1997; Burlakova et al., 2006; Mastitsky et al., 2010; Karatayev et al., 2012; Cichy et al., 2016), and there is evidence for parasite escape, i.e., fewer parasites in the invaded area as compared to the original range in the case of D. polymorpha (Molloy et al., 1997), but to our knowledge their parasite pressure has not been compared to sympatric native competitors at the same site.

One prediction of the Enemy Release Hypothesis is that introduced species should benefit from enemymediated competition because they are less likely to be affected by natural enemies than their native competitors (Elton, 1958; Keane and Crawley, 2002). The studies examining enemy-mediated competitive release, i.e., that invasive species benefit from competitive release as the native competitors are preferred by (native) enemies, compared enemy prevalence or enemy effects on invasive and native species in the introduced range (see Prior et al., 2015). In a recent review, studying parasites of sympatric native and invasive bivalve populations was pointed as one of the most important research needs with respect to invasion threats in conservation of endangered freshwater mussels conservation (Brian and Aldridge, 2019). Therefore, the aim of this study was to compare parasite pressure in sympatric populations of native and invasive bivalves, i.e. within-site differences in parasite species richness and summed prevalence of infection (see e.g., Torchin and Lafferty, 2009). This study can potentially contribute to the conservation of imperiled native mussels, as it should increase our knowledge and understanding of bivalve-parasite relationships, explore the explanations for success of invasions and possibly increase our ability to manage invasions.

Our study included eight European waterbodies which were inhabited by at least one of the three invasive bivalves-C. fluminea (Corbiculidae), $D$. polymorpha (Dreissenidae) and $S$. woodiana (Unionidae) - and at least one of the five native Unionidae mussels [Anodonta anatina (Linnaeus, 1758), A. cygnea (Linnaeus, 1758), Pseudanodonta complanata (Rossmässler, 1835), Unio pictorum (Linnaeus, 1758) and/or U. tumidus Philipsson, 1788]. D. polymorpha is originally from Black Sea and Caspian Sea drainages and has invaded Europe gradually since 1700s (Karatayev et al., 2007). C. fluminea and S. woodiana are both native to Asia and have colonized Europe since 1970-1980s (Watters, 1997; Lucy et al., 2012). Our hypothesis was that the invasive bivalves would have, on average, fewer parasite species and lower prevalence of infection than the native ones.

\section{Materials and methods}

Collection and examination of bivalves

The study was performed by collecting bivalves from sites where at least one native and one invasive bivalve species are living in sympatry, in the same particular site, to ensure that they are exposed to same parasites when they live in the same environment. Bivalve samples were collected from eight waterbodies, of which one was in Estonia and seven in Poland, between May and July during 2017-2018 (Table 1, Supplementary Tables 1-8). Collection was performed by hand picking (visual detection; with or without an aquascope), and-in Lake Gosławskie and Lake Siecino, Poland-also by snorkelling and scuba diving. The target sample size was 30 bivalve individuals per species per site. Characteristics of the study sites, with e.g., fish community and introduction of the invasive bivalves, are given in Supplementary Table 9.

Bivalves were stored on ice and examined fresh, except for samples from Lake Võrtsjärv, which were stored frozen. Parasite examination was performed by dissecting the bivalve, counting adult watermites (crawling on gills and mantle cavity), separating different tissues and examining the tissues, piece by piece, by pressing between two large glass plates and 
Table 1 Occurrence (X) of the 15 observed parasite taxa in each native (Anodonta anatina, Anodonta cygnea, Pseudanodonta complanata, Unio pictorum and Unio tumidus) and invasive (Sinanodonta woodiana, Dreissena polymorpha and Corbicula fluminea), all eight waterbodies combined

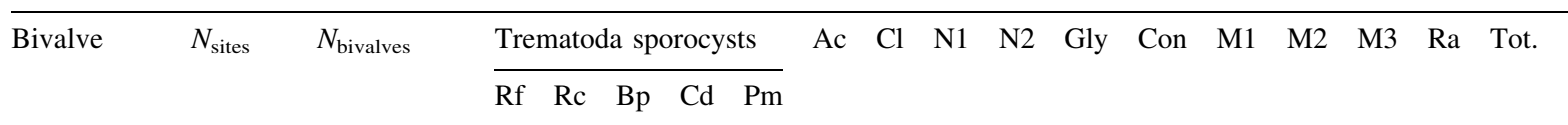

Native

\begin{tabular}{|c|c|c|c|c|c|c|c|c|c|c|c|c|c|c|c|c|c|c|}
\hline A.ana & 6 & 218 & $X$ & $\mathrm{X}$ & - & $X$ & - & $X$ & $\mathrm{X}$ & - & $X$ & $X$ & $X$ & $X$ & $X$ & $\mathrm{X}$ & - & 11 \\
\hline A.cyg & 2 & 67 & - & - & - & - & - & $X$ & $\mathrm{X}$ & - & - & - & $X$ & $X$ & $X$ & $X$ & $X$ & 7 \\
\hline P.com & 3 & 89 & - & - & - & - & - & - & $\mathrm{X}$ & - & - & $X$ & $X$ & $X$ & $X$ & $\mathrm{X}$ & - & 6 \\
\hline U.pic & 4 & 136 & - & - & - & - & - & $X$ & $\mathrm{X}$ & - & - & $X$ & $X$ & $X$ & $X$ & $X$ & $X$ & 8 \\
\hline U.tum & 6 & 173 & - & $\mathrm{X}$ & - & - & - & $X$ & $\mathrm{X}$ & - & - & $\mathrm{X}$ & $X$ & $X$ & $\mathrm{X}$ & $\mathrm{X}$ & $X$ & 9 \\
\hline $\begin{array}{c}N \text { of host } \\
\text { species }\end{array}$ & & & 1 & 2 & 0 & 1 & 0 & 4 & 5 & 0 & 1 & 4 & 5 & 5 & 5 & 5 & 3 & \\
\hline $\begin{array}{l}\text { Mean } \pm \text { s.e. } \\
\text { Invasive }\end{array}$ & $5.0 \pm 0.8$ & $136 \pm 27$ & & & & & & & & & & & & & & & & $8.2 \pm 0.9$ \\
\hline S.woo & 4 & 121 & - & $\mathrm{X}$ & - & - & - & - & $\mathrm{X}$ & - & - & $\mathrm{X}$ & - & $X$ & $\mathrm{X}$ & $\mathrm{X}$ & - & 6 \\
\hline D.pol & 6 & 170 & - & - & $X$ & - & $\mathrm{X}$ & - & - & $\mathrm{X}$ & - & $\mathrm{X}$ & $X$ & - & - & - & - & 5 \\
\hline C.flu & 2 & 85 & - & - & - & - & - & - & - & - & - & - & - & - & - & - & - & 0 \\
\hline Mean \pm s.e. & $4.0 \pm 1.2$ & $125 \pm 25$ & & & & & & & & & & & & & & & & $3.7 \pm 1.9$ \\
\hline $\begin{array}{c}N \text { of host } \\
\text { species }\end{array}$ & & & 0 & 1 & 1 & 0 & 1 & 0 & 1 & 1 & 0 & 2 & 1 & 1 & 1 & 1 & 0 & \\
\hline $\begin{array}{l}\text { Tot. } N \text { of } \\
\text { hosts }\end{array}$ & & & 1 & 3 & 1 & 1 & 1 & 4 & 6 & 1 & 1 & 6 & 6 & 6 & 6 & 6 & 6 & \\
\hline $\begin{array}{l}t \text {-test } \\
p \text {-value }\end{array}$ & 0.501 & 0.792 & & & & & & & & & & & & & & & & 0.043 \\
\hline
\end{tabular}

Numbers of waterbodies per bivalve species, the total number of individuals studied and the total number of observed parasite taxa per bivalve species are given in columns $N_{\text {sites }}, N_{\text {bivalves }}$ and Tot., respectively, and for these parameters the average values (Mean \pm s.e.) are given, as well as the $t$ test result (2-sided $p$-value) comparing the means of native and invasive bivalve species. Number of host species observed per parasite taxa is given separately for the native and the invasive bivalves. In addition, the total number of host species for each parasite taxon (combining the invasive and native bivalves) — a measure of host specificity of the parasite- is given on the row Tot. $N$ of hosts

Trematoda sporocysts = Tissue-dwelling, larval, (castrating) trematodes, Rf, Rhipidocotyle fennica; Rc, Rhipidocotyle campanula; $\mathrm{Bp}$, Bucephalus polymorphus; Cd, Cercaria duplicata and Pm, Phyllodistomum macrocotyle; Ac, Aspidogaster conchicola (adult trematode), Cl, Chaetogaster limnaei (Oligochaeta), N1, unknown larval nematode in gonad, N2, unknown larval nematode in gills; Gly, Glyptotendipes sp. (Chironomidae); Con, Conchophthirus sp. (Ciliata)

M1 = larval/egg stages of watermites in the mantle, M2 = larval/egg stages of watermites in the gills, M3 = adult watermites, Ra = Rhodeus amarus (bitterling)

inspecting with a preparation microscope using transmitted light (Taskinen et al., 1991). The tissues examined included mantle, gills, digestive gland and gonad, which are the typical sites of parasites in freshwater bivalves (e.g., Edwards and Vidrine, 2013; Taskinen et al., 1997). Bivalve sex was determined microscopically (presence and abundance of oocytes in gonad), and larval production as percentage of gill marsupia filled with glochidia was evaluated. In addition, shell measurements (length, width, height) and age determination (from annual growth rings on shell) were performed, but these aspects are not included in the present study. Numbers of parasites were counted or their abundance was estimated. If the mantle and gills were examined only from one side of the bivalves, the numbers were doubled. However, in the present analyses, only presence-absence data were used (prevalence of infection, i.e. the proportion of infected individuals), because summed prevalences have been previously used as a measure of parasite load in studies of Enemy Release Hypothesis (Lafferty et al., 2010; Torchin et al., 2003). Ciliates cannot be 
reliably observed from frozen samples. Therefore, ciliate parasites were not recorded for Lake Võrtsjärv since the bivalves from this lake were stored frozen.

\section{Statistical analyses}

We used parasite taxa richness (number of parasite taxa) and sum of prevalences (sum of the prevalence of all parasite taxa for each host species) as the response variables as they have generally been used as the measures of parasite pressure in studies exploring 'enemy release' (Lafferty et al., 2010; Torchin et al., 2003). First, a site-specific analysis was performed to get an idea of the bivalve and parasite community in a given waterbody. This was done by comparing prevalences of infection of every possible parasite taxa for each pair of native vs. invasive bivalve species using $\chi^{2}$-test. If the number of cells with an expected count value lower than five was greater than one, a Yates continuity correction (Sokal and Rohlf, 1981) was applied.

In addition, if there was at least three native and invasive bivalve species in a given site, difference in the mean prevalence of a given parasite taxon between native and invasive bivalves was analysed using t-test (for example, see Gosławskie Lake, Supplementary Table 3). This approach did not differentiate the bivalve species. For instance, mean value for the invasive species $S$. woodiana, $D$. polymorpha and $C$. fluminea against the mean value of the native species A. anatina, $U$. pictorum and $U$. tumidus was used in the case of Gosławskie Lake, without taking into consideration possible differences between the three invasive or between the three native bivalve species. However, this approach was in line with our hypothesis, that "invasive bivalves would have, on average, fewer parasite species and lower prevalence of infection than the native ones", which does not separate bivalve species within the native or invasive group. Detailed reports of these site-specific analyses, where all possible native vs. invasive bivalve combinations are analysed for each parasite taxon, are given in "Sitespecific results" of the Supplementary materials and in Supplementary Tables $1-8$.

Second, to get a comprehensive picture over the all studied waterbodies, the average number of parasite taxa and the average sum of prevalences pooled for all invasive $v s$. native bivalves per site were used as the response variables in comparisons performed over all sites between invasive and native bivalves (for example, see Fig. 1). If only one native or invasive bivalve species was present, its values represented the average for native/invasive group in that lake. Then these averages were used in a $t$-test to analyse within-site differences in the mean average parasite taxa richness and summed prevalences between the native and invasive bivalves. In this approach, for each site, only those bivalve species were included in the statistical analyses for which the number of individuals was at least 15 . This was done to avoid biases due to different sample size, because even though the aim was to collect and study 30 individuals per bivalve species per site, this was not always possible (see Table 1 and Supplementary Tables 1-8).

The second procedure (above) was also applied to the number of bivalve individuals collected to estimate the possible difference in sample sizes for the native and invasive bivalves. Mean ( \pm s.e.) average number of bivalves studied was $32 \pm 4$ and $30 \pm 3$ for the native and invasive bivalves, respectively. The difference was statistically not significant indicating that sample sizes for the native and invasive bivalves over the eight study sites did not differ from each other (paired $t$-test, $n=8, t=0.506$, df $=7, p=0.629$ ) (see Supplementary Tables $1-8$ for details).

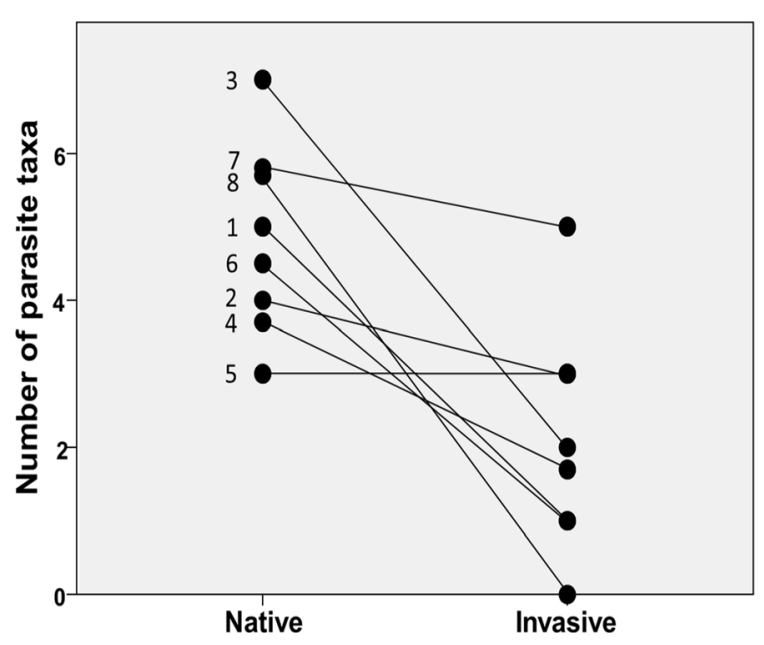

Fig. 1 Mean parasite taxa richness for native and invasive freshwater bivalves in eight northern European waterbodies. 1-Lake Võrtsjärv, 2-Czarny Młyn Pond, 3-Warta-Gopło Canal, 4-Gosławskie Lake, 5-Nowy Lipsk Pond, 6-Siecino Lake, 7-Szeszupa River, 8-Rospuda River. Values connected by a line belong to the same study site. Mean number of parasite taxa was significantly higher in native bivalves as compared to invasive bivalves (paired $t$-test, $p=0.008$ ) 
Differences were regarded as statistically significant, when $p<0.050$. When $0.050 \leq p \leq 0.099$, the difference was interpreted as marginally significant, indicating that there is a trend, but the risk of wrong conclusion is increased.

\section{Results}

Five native (A. anatina, A cygnea, P. complanata, $U$. pictorum and $U$. tumidus) and three invasive ( $S$. woodiana, D. polymorpha and $C$. fluminea) freshwater bivalve species and a total of 15 parasite taxa (Rhipidocotyle fennica Gibson et al., 1992, R. campanula (Dujardin, 1845), Bucephalus polymorphus von Baer, 1827, Cercaria duplicata von Baer, 1827, Phyllodistomum macrocotyle (Lühe, 1909), Aspidogaster conchicola von Baer, 1827, Chaetogaster limnaei von Baer, 1827, unknown larval nematode from gonad, unknown larval nematode from gills, Glyptotendipes sp. (Lenz), Conchophthirus sp. (Claparéde and Lachmann), larval/egg stages of watermites in the mantle, larval/egg stages of watermites in the gills, adult watermites and larvae of bitterling Rhodeus amarus (Bloch, 1872) were discovered from the eight waterbodies (Table 1).

Mean $( \pm$ s.e.) average parasite taxa richness over the eight study sites was 2.3 times higher for the native than for the invasive bivalves $(4.8 \pm 0.5$ vs. $2.1 \pm 0.6$ taxa; range 3-7 and 0-5 taxa, respectively), the difference being statistically significant (paired $t$ test, $n=8, t=3.703$, df $=7, p=0.008$ ) (Fig. 1). Furthermore, the mean ( \pm s.e.) average summed prevalence of infections of different parasites over the eight study sites was 2.4 times higher for the native than for the invasive bivalves $(151 \pm 27$ vs. $64 \pm 24$ $\%$, range 43-264 and 0-170\%, respectively), the difference being statistically significant (paired $t$ test, $n=8, t=2.378, \mathrm{df}=t, p=0.049$ ) (Fig. 2).

Anodonta anatina $\left(n_{\mathrm{tot}}=218\right.$ individuals) was found from six out of eight sites and harboured in total 11 different parasite taxa, while A. cygnea $\left(n_{\text {tot }}=67\right)$ was found from two waterbodies and harboured altogether seven parasite taxa (Table 1). Corresponding figures for $P$. complanata $\left(n_{\mathrm{tot}}=89\right)$ were three lakes/rivers and six parasite taxa, for $U$. pictorum $\left(n_{\text {tot }}\right.$ = 136) four sites and eight parasite taxa and for $U$. tumidus $\left(n_{\text {tot }}=173\right)$ six waterbodies and nine parasite taxa (Table 1). Of the invasive mussels, $S$. woodiana

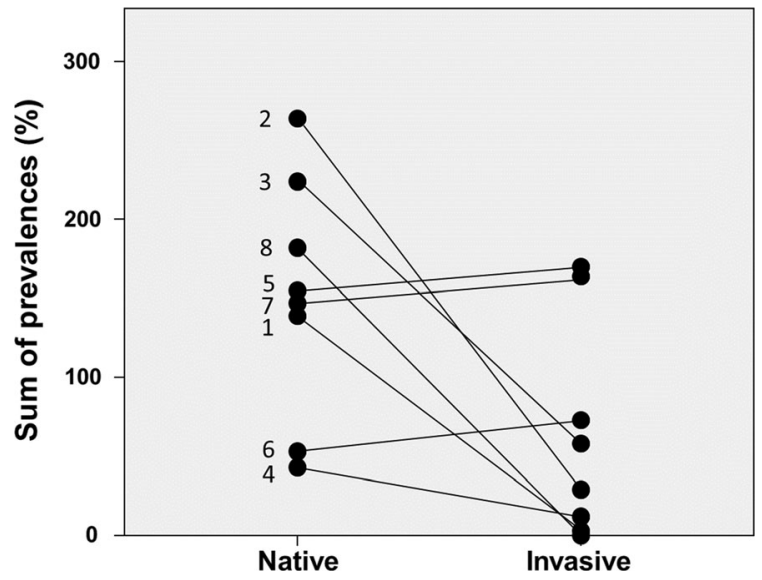

Fig. 2 Mean sum of prevalences of infection of different parasites for native and invasive freshwater bivalves in eight northern European waterbodies. 1-Lake Võrtsjärv, 2-Czarny Młyn Pond, 3-Warta-Gopło Canal, 4-Gosławskie Lake, 5Nowy Lipsk Pond, 6-Siecino Lake, 7-Szeszupa River, 8Rospuda River. Values connected by a line belong to the same study site. Mean sum of infection prevalences of parasites was significantly higher in native bivalves than in the invasive ones (paired $t$-test, $p=0.049$ )

( $n_{\mathrm{tot}}=121$ individuals) was found from four lakes/ rivers and harboured six different parasite taxa, and $D$. polymorpha $\left(n_{\mathrm{tot}}=170\right)$ was found from six waterbodies and harboured five parasite taxa, while $C$. fluminea $\left(n_{\mathrm{tot}}=85\right)$ was found from two sites and did not harbour any parasites (Table 1 ). The total parasite pool infecting native mussels consisted of 12 taxa while that of invasive bivalves included 10 parasite taxa (Table 1). When combiner over the eight waterbodies, the total number of parasite taxa infecting each native and invasive mussel species varied from six to 11 and from zero to six per bivalve species, respectively (Table 1$)$. The mean ( \pm s.e.) total number of observed parasite taxa for native and invasive bivalves (per bivalve species, combined over all sites) was 8.2 \pm 0.9 and $3.7 \pm 1.9$, respectively, the difference being statistically significant ( $t$-test, $t=2.553, \mathrm{df}=6, p=$ 0.043) (Table 1).

Site-specific results with parasite taxon-specific comparisons between all possible combinations of native and invasive mussels revealed statistically significant differences with respect to all parasite taxa other than B. polymorphus, C. duplicata and the unknown nematodes from gonad and gills (Supplementary Tables 1-8). 


\section{Discussion}

Detailed discussion on results of each of the eight sites is provided in Supplementary Materials. In addition, parasite-specific discussion with respect to life cycles, hosts, host specificity and earlier findings of geographic distributions (Dimock and LaRochelle, 1980; Davids et al., 1988; Taskinen et al., 1991; Gibson et al., 1992; Conn et al., 1996; Vidrine, 1996; Fried and Graczyk, 1997; Molloy et al., 1997; Taskinen, 1998a; Jokela et al., 2005; Edwards and Vidrine, 2006; Ibrahim, 2007; Reichard et al., 2007; Mastitsky et al., 2010; Mastitsky and Veres, 2010; Edwards and Vidrine, 2013; Cichy et al., 2016; Rouchet et al., 2017) is also give in Supplementary Materials.

Enemy Release Hypothesis (Elton, 1958) suggests that invasive species should lose parasites during the invasion process, which should lead to a lower parasite load in the new, introduced range, benefitting the invaders in competition against the local, native competitors. Large body of empirical evidence indicates that the invaders, indeed, are frequently released from parasites when introduced to new area (Mitchell and Power, 2003; Torchin et al., 2003). One prediction of the Enemy Release Hypothesis is that introduced species should benefit from enemy-mediated competitive release because they are less likely to be affected by natural enemies than their native competitors (Elton, 1958; Keane and Crawley, 2002). Therefore, we compared parasite pressure of invasive and native freshwater bivalves living in sympatry. The overall mean site-specific average parasite taxon richness and sum of prevalences were, both, more than two times higher among the native bivalves than in the invasive bivalves. Site-specific comparisons between pairs of native and invasive bivalves at individual parasite taxon level frequently also indicated higher parasite prevalence in the native bivalve than in the invasive counterpart. Thus, the results support the Enemy Release Hypothesis and the view that the invasive bivalves benefit from a lower parasite pressure than the sympatric populations of native species.

A prerequisite of enemy-mediated competitive release is that parasitism is a cost, i.e., parasites must be harmful. Larval trematodes using bivalve as the $1^{\text {st }}$ intermediate host (bucephalids, gorgoderids) are inevitably very harmful, causing partial or complete sterility, parasite-induced mortality and lowered growth (Davids and Kraak, 1993; Taskinen and
Valtonen, 1995; Taskinen, 1998b; Jokela et al., 2005; Müller et al., 2014). Adult watermites ingest mucus and tissues of their bivalve host (Fisher et al., 2000). Results by Gangloff et al. (2008) suggest that ectoparasitic adult watermites (Unionicola spp.) and ectoparasitic adult trematodes (Aspidogaster spp.) are strongly negatively associated with both physiological condition (glycogen) and reproductive output of bivalve. Numbers of eggs/larval stages of watermites in the present study were very high-up to thousands of eggs/larval mites embedded in mantle tissue of a single mussel individual, for example, suggesting potential for high virulence. The effect of echinostomatid trematode metacercariae on mussel host is usually benign (Laruelle et al., 2002), but bitterling ( $R$. amarus) embryos can be costly to a mussel (Reichard et al., 2006). Therefore, many of the parasites of the present study are potentially costly to host bivalve, and the higher parasite prevalences in native bivalves should benefit the invasive competitors.

Another prerequisite of enemy-mediated competitive release is that there must be competition between native and invasive bivalves. Freshwater bivalves can be assumed to compete with each other as they all are benthic filter feeders, thereby sharing the same ecological niche in terms of food and space. As mentioned earlier, invasive bivalves can remarkably harm native mussels either directly (biofouling by e.g. zebra mussel Dreissena polymorpha) or indirectly via competition over food, space or host fish or by changing the bottom habitat (reviewed by Sousa et al., 2014). Competition between native and invasive mussels is indicated by the negative correlation between their densities on local scale (Vaugh and Spooner, 2006) and illustrated, for example, by the rapid decline of native mussels after introduction of Dreissena to North American Great Lakes (Strayer and Malcom, 2007).

Invasive species can acquire parasites in the invaded area either by bringing them along themselves or by infection by parasites of the native species. If bivalves are introduced as larvae, probability that they transport their own parasites to the invaded area is close to zero. Introduction of D. polymorpha to North America and $S$. woodiana to Europe have happened presumably by veliger and glochidium larvae, respectively (Watters, 1997; Karatayev et al., 2007), though the introduction and spread of D. polymorpha in Europe might have also occurred at an adult stage 
(Burlakova et al., 2006). Consequently, North American D. polymorpha populations have no records of original parasites of $D$. polymorpha while those in Europe have (Burlakova et al., 2006) and they were also observed in the present study (trematodes $B$. polymorphus and $P$. macrocotyle). Based on the few studies on invasive hosts and parasites, adaptation of novel hosts/parasites to those in the introduced region is, in general, a long process (Taraschewski, 2006), but Karatayev et al. (2012) observed that $D$. polymorpha has acquired echinostomatids from native hosts in North America 26 year after it was first time recorded. Thus, it is possible that some of the parasites of native mussels have jumped to D. polymorpha also in Europe during the up to 200 years of invasion. Results of Petkeviciute et al. (2014) support the view that the gorgoderid trematode $P$. macrocotyle is a specific parasite of $D$. polymorpha, while $C$. duplicata is specific to unionid mussels. Similarly, Taskinen et al. (1991) concluded that the bucephalid trematode $B$. polymorphus is a specific parasite of $D$. polymorpha, while $R$. fennica and $R$. campanula are specific to unionids. So, at least $B$. polymorphus and P. macrocotyle were brought to Europe by $D$. polymorphathey did not jump to $D$. polymorpha from native mussels-meaning that $D$. polymorpha was not released from these two enemies during the invasion process. In spite of this, the prevalence of infection was always (when possible to analyse) higher in the native counterpart(s) than in D. polymorpha-except for P. macrocotyle, a Dreissena-specific trematode, and Conchophthirus ciliate-in Szeszupa River (Suppl. Table 7). There are at least five Dreissenaspecific ciliate parasites including Conchophthirus acuminatus (Claparéde and Lachmann, 1858) and $C$. klimentinus (Molloy et al., 1997). Thus, it is possible that the high Conchophthirus infection of D. polymorpha in Szezszupa River was caused by a ciliate species specific to $D$. polymorpha.

In addition to almost always lower parasite load in D. polymorpha (except for the D. polymorpha-specific trematodes), when compared to native bivalves the complete absence of parasites in $C$. fluminea was striking (Suppl. Table 3,4) and strongly supports the view of parasite benefit for $C$. fluminea when competing with native bivalves. In its original range, C. fluminea has been reported to host Phyllodistomum mingensis (Tang, 1985), five species of Echinostoma (Keeler and Huffman 2009) and seven species of
Aspidogastrea (Tang, 1992). Parasite escape by introduced $C$. fluminea has been observed also in North America. Despite a long history of C. fluminea research since their introduction in 1930s, only the host-generalist aspidogastrid trematodes $A$. conchicola and Cotylapsis insignis Leidy, 1857, have been reported from North America (Danford and Joy, 1984). In addition, Karatayev et al. (2012) also did not find any parasites from $C$. fluminea from Great Lakes area except echinostomatid metacercqriae in one out of 27 sites. Thus, besides the European waterbodies studied here, $C$. fluminea seem to enjoy a remarkable reduction of parasite pressure also in other regions it has invaded globally.

A meta-analysis revealed that a significantly higher extent of parasite escape is evident in aquatic than in terrestrial environments, possibly due to less frequent introductions per invader and introduction as a larval form free of parasites (Lafferty et al., 2010). Results by Mastitsky et al. (2010) indicate that over one third of invasive freshwater invertebrates did not successfully introduce any of their coevolved parasites to the invaded areas. Our results suggest that in the introduced range, the invasive freshwater bivalves may enjoy lower parasite pressure, i.e., have lower number of parasite species and lower combined prevalence of infection, than their native counterparts, giving a 'parasite benefit' for the invasive bivalves in competition against the native ones. However, the within-site variation between the native species was also relatively high in our study — not all native species were always strongly infected. In addition, variation between the invasive species was also large, from not-a-single-parasite in the Asia clam C. fluminea to considerably high values of parasite parameters in the Chinese pond mussel $S$. woodiana in Warta-Gopło Canal and Nowy Lipsk Pond (Suppl. Table 3, 5). This will rise many questions, for example: Are the parasites of European unionids better able to infect another unionid, S.woodiana, than phylogenetically distinct dreissenids or corbiculids-even if S. woodiana is a recent invader compared to e.g. Dreissena? Therefore, to better understand the role of parasites in invasions of freshwater bivalves, the importance of parasitism should be studied in relation to the genetic (and geographic) distance between the introduced and native bivalves, and in relation to time since introduction and routes of invasions-from both the host bivalves' and parasites' perspectives. 
Freshwater mussels Unionida are important in maintaining aquatic biodiversity and ecosystem functions (Vaughn, 2018). Invasive bivalves can have devastating effects on the native mussels and on the whole freshwater ecosystems (Higgins and Vander Zanden, 2010; Sousa et al., 2014). So, research on the interplay between parasites, bivalves and invasions will potentially increase our understanding how hostparasite relationships are shaping the outcomes of invasions. This may thereby possibly contribute to our ability to manage invasions and protect imperiled native bivalves and aquatic ecosystems.

Acknowledgements Open access funding provided by University of Jyväskylä (JYU). Co-authors' cooperation was initiated with the support of the Poznań City Council under the "Academic and Scientific Poznań" Program. The study was funded by Estonian Ministry of Education and Research (institutional research funding project IUT 21-2 to Tiina Nõges) and by Estonian Research Council, Mobilitas Pluss research project MOBJD29. This study was also supported by the Polish Minister of Science and Higher Education, under the program "Regional Initiative of Excellence" in 2019-2022 (Grant No. 008/RID/2018/19), by Poznań University of Life Sciences, University of Jyväskylä, and by CNR Short Term Mobility Project 2016. We thank Henryk Gierszal and Henn Timm for valuable assistance in field and laboratory.

Open Access This article is licensed under a Creative Commons Attribution 4.0 International License, which permits use, sharing, adaptation, distribution and reproduction in any medium or format, as long as you give appropriate credit to the original author(s) and the source, provide a link to the Creative Commons licence, and indicate if changes were made. The images or other third party material in this article are included in the article's Creative Commons licence, unless indicated otherwise in a credit line to the material. If material is not included in the article's Creative Commons licence and your intended use is not permitted by statutory regulation or exceeds the permitted use, you will need to obtain permission directly from the copyright holder. To view a copy of this licence, visit http://creativecommons.org/licenses/by/4.0/.

\section{References}

Anderson, R. M. \& R. M. May, 1979. Population biology of infectious diseases. Part I. Nature 280: 361-367.

Blakeslee, A. M. H., A. E. Fowler \& C. L. Keogh, 2013. Marine Invasions and Parasite Escape: Updates and New Perspectives. In Lesser, M. (ed.), Advances in Marine Biology. Elsevier, Amsterdam: 87-169.

Brian, J. I. \& D. C. Aldridge, 2019. Endosybionts: An overlooked threat in the conservation of freshwater mussels? Biological Conservation 237: 155-165.
Burlakova, L. E., D. K. Padilla, A. Y. Karatayev \& D. Minchin, 2006. Endosymbionts of Dreissena polymorpha in Ireland: evidence for the introduction of adult mussels. Journal of Molluscan Studies 72: 207-210.

Carella, F., G. Villari, N. Maio \& G. De Vico, 2016. Disease and disorders of freshwater unionid mussels: A brief overview of recent studies. Frontiers in Physiology 7(489): 1-8.

Cichy, A., M. Urbanska, A. Marszewska, W. Andrzejewski \& E. Zbikowska, 2016. The invasive Chinese pond mussel Sinanodonta woodiana (Lea, 1834) as a host for native symbionts in European waters. Journal of Limnology 75 : 288-296.

Conn, D. B., A. Ricciardi, M. N. Babapulle, K. A. Klein \& D. A. Rosen, 1996. Chaetogaster limnaei (Annelida: Oligochaeta) as a parasite of the zebra mussel Dreissena polymorpha, and the quagga mussel Dreissena bugensis (Mollusca: Bivalvia). Parasitology Research 82(1): 1-7.

Danford, D. W. \& J. E. Joy, 1984. Aspidogastrid (Trematoda) parasites of bivalve molluscs in western West Virginia. Proceedings of the Helminthological Society of Washington 51: 301-305.

Davids, C., J. Holtslag \& R. V. J. Dimock, 1988. Competitive exclusion, harem behavious and host specificity of the water mite Unionicola ypsilophora (Hydrachnellae, Acari) inhabiting Anodonta cygnea (Unionidae). International Revue gesHyrdobiologie 73: 651-657.

Davids, C. \& M. H. S. Kraak, 1993. Trematode parasites of the zebra mussel (Dreissena polymorpha). In Nalepa, T. F. \& D. W. Schloesser (eds.), Zebra Mussels: Biology, Impacts, and Control. Lewis Publishers, Boca Raton: 749-759.

Dimock, R. V. J. \& P. B. LaRochelle, 1980. Chemically mediated host recognition: a behavioural basis for the host specificityof water mites symbioses. American Zoologist 26: 922.

Donrovich, S. W., K. Douda, V. Plechingerová, K. Rylková, P. Horký, O. Slavík, H.-Z. Liu, M. Reichard, M. Lopes-Lima $\&$ R. Sousa, 2016. Invasive Chinese pond mussel Sinanodonta woodiana threatens native mussel reproduction by inducing cross-resistance of host fish. Aquatic Conservation: Marine and Freshwater Ecosystems 2017(00): 1-9.

Douda, K., M. Vrtilek, O. Slavik \& M. Reichard, 2012. The role of host specificity in explaining the invasion success of the freshwater mussel Anodonta woodiana in Europe. Biological Invasions 14: 127-137.

Dzierżyńska-Białończyk, A., Ł. Jermacz, T. Mackiewicz, J. Gajewska \& J. Kobak, 2018. Mechanisms and impact of differential fouling of the zebra mussel Dreissena polymorpha on different unionid bivalves. Freshwater Biology 63: 687-699.

Edwards, F. D. \& M. F. Vidrine, 2006. Host specificity among Unionicola spp (Acari: Inionicolidae) parasitizing freshwater mussels. Journal of Parasitology 92(5): 977-983.

Edwards, F. D. \& M. F. Vidrine, 2013. Mites of Freswater Mollusks. Malcom. F, Vidrine, Eunice, Louisiana, USA.

Elton, C. S., 1958. The Ecology of Invasions by Animals and Plants. Methuen, London.

Ferreira-Rodríguez, N., Y. B. Akiyama, O. V. Aksenova, R. Araujo, M. C. Barnhart, Y. V. Bespalaya, A. E. Bogan, I. N. Bolotov, P. B. Budha, C. Clavijo, S. J. Clearwater, G. Darrigran, V. T. Do, K. Douda, E. Froufe, C. Gumpinger, L. Henrikson, C. L. Humphrey, N. A. Johnson, O. Klishko, 
M. W. Klunzinge, S. Kovitvadhi, U. Kovitvadhi, J. Lajtner, M. Lopes-Lima, E. A. Moorkens, S. Nagayama, K.-O. Nagel, M. Nakano, J. N. Negishi, P. Ondina, P. Oulasvirta, V. Prié, N. Riccardi, M. Rudzīte, F. Sheldon, R. Sousa, D. L. Strayer, M. Takeuchi, J. Taskinen, A. Teixeira, J. S. Tiemann, M. Urbańska, S. Varandas, M. V. Vinarski, B. J. Wicklow, T. Zając \& C. C. Vaughan, 2019. Research priorities for freshwater mussel conservation assessment. Biological Conservation 231: 77-87.

Ferreira-Rodriguez, N., R. Sousa \& I. Pardo, 2018. Negative effects of Corbicula fluminea over native freshwater mussels. Hydrobiologia 810: 85-95.

Fisher, G. R., R. V. J. Dimock \& R. E. Kuhn, 2000. The symbiotic water mite Unionicola formosa (Acari: Unionicolidae) ingests mucus and tissue of its molluscan host. Journal of Parasitology 86(6): 1254-1258.

Fried, B. \& T. K. Graczyk, 1997. Advances in Trematode Biology. CRC Press, Boca Raton, Florida.

Gangloff, M. M., K. K. Lenertz \& J. W. Feminella, 2008. Parasitic mite and trematode abundance are associated with reduced reproductive output and physiological condition of freshwater mussels. Hydrobiologia 610: 25-31.

Gibson, D. I., E. T. Valtonen \& J. Taskinen, 1992. Studies on bucephalid digeneans parasitising molluses and fishes in Finland. II. The description of Rhipidocotyle fennica $\mathrm{n}$. sp. and its discrimination by principal component analysis. Systematic Parasitology 23: 67-79.

Grizzle, J. M. \& C. J. Brunner, 2009. Infectious diseases of freshwater mussels and other freshwater bivalve mollusks. Reviews in Fihseries Science 17(4): 425-467.

Haag, W. R., D. J. Berg, D. W. Garton \& J. L. Farris, 1993. Reduced survival and fitness in native bivalves in response to fouling by the introduced zebra mussel (Dreissena polymorpha) in western Lake Erie. Canadian Journal of Fisheries and Aquatic Sciences 50: 13-19.

Higgins, S. N. \& M. J. Vander Zanden, 2010. What a difference a species makes: a meta-analysis of dreissenid mussel impacts on freshwater ecosystems. Ecological Monographs 80: 179-196.

Hudson, P. J., A. P. Dobson \& D. Newborn, 1998. Prevention of population cycles by parasite removal. Science 282: 2256-2258.

Ibrahim, M. M., 2007. Population dynamics of Chaetogaster limnaei (Oligochaeta: Naididae) in the field populations of freshwater snails and its implications as a potential regulator of trematode larvae. Parasitology Research 101: 25-33.

Jokela, J., J. Taskinen, P. Mutikainen \& K. Kopp, 2005. Virulence of parasites in hosts under environmental stress: experiments with anoxia and starvation. OIKOS 108: $156-164$.

Karatayev, A. Y., L. E. Burlakova \& D. K. Padilla, 1997. The effects of Dreissena polymorpha (Pallas) invasion on aquatic communities in eastern Europe. Journal of Shellfish Research 16: 187-203.

Karatayev, A. Y., S. E. Mastitsky, L. E. Burlakova, V. A. Karatayev, M. M. Hajduk \& D. B. Conn, 2012. Exotic molluscs in the Great Lakes host epizootically important trematodes. Journal of Shellfish Research 31: 885-894.

Karatayev, A. Y., D. K. Padilla, D. Minchin, D. Boltovskoy \& L. E. Burlakova, 2007. Changes in global economies and trade: the potential spread of exotic freshwater bivalves. Biological Invasions 9: 161-180.

Keane, R. M. \& M. J. Crawley, 2002. Exotic plant invasions and the enemy release hypothesis. Trends in Ecology and Evolution 21: 381-385.

Keeler, S. P. \& J. E. Huffman, 2009. Echinostomes in the second intermediate host. In Toledo, R. \& B. Fried (eds.), The biology of echinostomes: from the molecule to the community. Springer, New York, USA: 61-87.

Keller, R. P., J. Geist, J. M. Jeshke \& I. Kuehn, 2011. Invasive species in Europe: ecology, status and policy. Environmental Sciences Europe 23: 23.

Labecka, A. M. \& J. Domagała, 2018. Continuous reproduction of Sinanodonta woodiana (Lea, 1824) females: an invasive mussel species in a female-biased population. Hydrobiologia. https://doi.org/10.1007/s10750-016-2835-2.

Lafferty, K. D., M. E. Torchin \& A. M. Kuris, 2010. The geography of host and parasite invasions. In Morand, S. \& B. R. Krasnov (eds.), The Biogeography of Host-Parasite Interactions. Oxford University Press, New York, USA: 191-203.

Laruelle, F., D. P. Molloy \& V. Roitman, 2002. Histological analysis of trematodes in Dreissena polymorpha: their location, pathogenicity, and distinguishing morphological characteristics. Journal of Parasitology 88: 856-863.

Lockwood, J. L., M. F. Hoopes \& M. P. Marchetti, 2013. Invasion Ecology, 2nd, Edition ed. Wiley-Blackwell, West Sussex, UK.

Lopes-Lima, M., R. Sousa, J. Geist, D. C. Aldridge, R. Araujo, J. Bergengren, Y. Bespalaya, E. Bodis, L. Burlakova, D. van Damme, K. Douda, E. Froufe, D. Georgiev, C. Gumpinger, A. Karatayev, U. Kebapc, I. Kileen, L. Lajtner, B. M. Larsen, R. Lauceri, A. Legakis, S. Lois, S. Lundberg, E. Moorkens, G. Motte, K.-O. Nagel, P. Ondina, A. Outeiro, M. Paunovic, V. Prie, T. von Proschwitz, N. Riccardi, M. Rudzite, M. Rudzitis, C. Scheder, M. Seddon, H. Sereflisan, V. Simic, S. Sokolova, K. Stoekl, J. Taskinen, A. Teixeira, F. Thielen, T. Trichkova, S. Varandas, H. Vicentini, K. Zajac, T. Zajac \& S. Zogaris, 2017. Conservation status of freshwater mussels in Europe: state of the art and future challenges. Biological Reviews 92: 572-607.

Lucy, F. E., A. Y. Karatayev \& L. E. Burlakova, 2012. Predictions for the spread, population density, and impacts of Corbicula fluminea in Ireland. Aquatic Invasions 7(4): 465-474.

Lydeard, C., R. H. Cowie, W. F. Ponder, A. E. Bogan, P. Bouchet, S. A. Clark, K. S. Cummings, T. J. Frest, O. Gargominy, D. G. Herbert, R. Hershler, K. E. Perez, B. Roth, F. G. Thompson, et al., 2004. The global decline of nonmarine mollusks. Bioscience 54(4): 321-330.

Mastitsky, S. E., A. Y. Karatayev, L. E. Burlakova \& D. P. Molloy, 2010. Parasites of exotic species in invaded areas: does lower diversity mean lower epizootic impact? Diversity and Distributions 16: 798-803.

Mastitsky, S. E. \& J. K. Veres, 2010. Field evidence for a parasite spillback caused by exotic mollusc Dreissena polymorpha in an invaded lake. Parasitology Research 106: $667-675$.

May, R. M. \& R. M. Anderson, 1979. Population biology of infectious diseases: Part II. Nature 280: 455-461. 
Mitchell, C. E. \& A. G. Power, 2003. Release of invasive plants from fungal and viral pathogens. Nature 421: 625-627.

Modesto, V., P. Castro, M. Lopes-Lima, C. Antunes, M. Ilarri \& R. Sousa, 2019. Potential impacts of the invasive species Corbicula fluminea on the survival of glochidia. Science of The Total Environment 673: 157-164.

Molloy, D. P., A. Y. Karatayev, L. E. Burlakova, D. P. Kurandina \& F. Laruelle, 1997. Natural enemies of zebra mussels: Predators, parasites, and ecological competitors. Reviews in Fisheries Science 5(1): 27-97.

Müller, T., M. Czarnoleski, A. M. Labecka, A. Cichy, K. Zajac \& D. Dragosz-Kluska, 2014. Factors affecting trematode infection rates in freshwater mussels. Hydrobiologia. https://doi.org/10.1007/s10750-014-1965-7.

Olden, J. D., N. L. Poff, M. R. Douglas, M. E. Douglas \& K. D. Fausch, 2004. Ecological and evolutionary consequences of biotic homogenization. Trends in Ecology and Evolution 19: 18-24.

Ożgo, M., M. Urbańska, P. Hoos, H. K. Imhof, M. Kirschenstein, J. Mayr, F. Michl, R. Tobiasz, M. Wesendonk, S. Zimmermann \& J. Geist, 2020. Invasive zebra mussel (Dreissena polymorpha) threatens an exceptionally large population of the depressed river mussel (Pseudanodonta complanata) in a postglacial lake. Ecology and Evolution 2020: 1-10.

Petkeviciute, R., V. Stunzenas, G. Staneviciute \& A. E. Zhokhov, 2014. European Phyllodistomum (Digenea, Gorgoderidae) and phylogenetic affinities of Cercaria duplicata based on rDNA and karyotypes. Zoologica Scripta 44: 191-202.

Pimentel, D., R. Zuninga \& D. Morrison, 2005. Update on the environmental and economic costs associated with alieninvasive species in the United States. Ecological Economics 52: 237-288.

Price, P. W., 1980. Evolutionary biology of parasites. Princeton University Press, Princeton, New Jersey.

Prior, K. M., T. H. Q. Powell, A. L. Joseph \& J. J. Hellman, 2015. Insights from community ecology into the role of enemy release in causing invasion success: the importance of native enemy effects. Biological Invasions 17: 1283-1297.

Reichard, M., M. Ondrackova, M. Przybylski, H. Liu \& C. Smith, 2006. The costs and benefits in an unusual symbiosis: experimental evidence that bitterling fish (Rhodeus sericeus) are parasites of unionid mussels in Europe. Journal of Evolutionary Biology 19: 788-796.

Reichard, M., M. Przybylski, P. Kaniewska, H. Liu \& C. Smith, 2007. A possible evolutionary lag in the relationship between freshwater mussels and European bitterling. Journal of Fish Biology 70: 709-725.

Rouchet, R., C. Smith, L. Huanzhang, L. Methling, K. Douda, D. Yu, Q. Tang \& M. Reichard, 2017. Avoidance of host resistance in the oviposition-site preferences of rose bitterling. Evolutionary Ecology. https://doi.org/10.1007/ s10682-017-9907-2.

Saarinen, M. \& J. Taskinen, 2005. Local adaptation in a crustacean parasite-molluscan host interaction: a field experiment. Evolutionary Ecology Research 7: 1-9.

Sokal, R. R. \& F. J. Rohlf, 1981. Biometry: The Principles and Practice of Statistics in Biological Research. W.H. Freeman, Oxford.
Sousa, R., J. L. Gutierrez \& D. C. Aldridge, 2009. Nonindigenous invasive bivalves as ecosystem engineers. Biological Invasions 11: 2367-2385.

Sousa, R., A. Novais, R. Costa \& D. Strayer, 2014. Invasive bivalves in fresh waters: impacts from individuals to ecosystems and possible control strategies. Hydrobiologia 735: 233-251.

Strayer, D. L., L. C. Smith \& D. C. Hunter, 1998. Effects of the zebra mussel (Dreissena polymorpha) invasion on the macrobenthos of the freshwater tidal Hudson River. Canadian Journal of Zoology/Revue Canadien de Zoologie 76(3): 419-425.

Strayer, D. L. \& H. M. Malcom, 2007. Effects of zebra mussels (Dreissena polymorpha) on native bivalves: the beginning of the end or the end of the beginning? Journal of the North American Benthological Society 26: 111-122.

Tang, C., 1992. Some larval trematodes from marine bivalves of Honk Kong and freshwater bivalves of costal China. In Morton, B. (ed.), The marine flora and fauna of Honk Kong and southern China III, Vol. 1. Hong Kong University Press, Hong Kong: 17-29.

Tang, Z., 1985. Studies on the life history of Phyllodistomum mingensis. Acta Zoologica Sinensis 31: 246-253.

Taraschewski, H., 2006. Hosts and parasites as aliens. Journal of Helminthology 80: 99-128.

Taskinen, J., 1998a. Cercarial production of the trematode Rhipidocotyle fennica in clams kept in the field. Journal of Parasitology 84: 345-349.

Taskinen, J., 1998b. Influence of trematode parasitism on the growth of a bivalve host in the field. International Journal for Parasitology 28: 599-602.

Taskinen, J., T. Mäkelä \& E. T. Valtonen, 1997. Exploitation of Anodonta piscinalis (Bivalvia) by trematodes: Parasite tactics and host longevity. Annales Zoologici Fennici 34(1): 37-46.

Taskinen, J. \& E. T. Valtonen, 1995. Age-, size-, and sexspecific infection of Anodonta piscinalis (Bivalvia: Unionidae) with Rhipidocotyle fennica (Digenea: Bucephalidae) and its influence on host reproduction. Canadian Journal of Zoology 73(5): 887-897.

Taskinen, J., E. T. Valtonen \& D. I. Gibson, 1991. Studies on bucephalid digeneans parasitising molluscs and fishes in Finland. I. Ecological data and experimental studies. Systematic Parasitology 19: 81-94.

Torchin, M. E., K. D. Lafferty, A. P. Dobson, V. J. McKenzie \& A. M. Kuris, 2003. Introduced species and their missing parasites. Nature 421: 628-630.

Torchin, M. E. \& K. D. Lafferty, 2009. Escape from parasites. In Rilov, G. \& J. A. Crooks (eds.), Biological Invasions in Marine Ecosystems: ecological, management and geographic perspectives. Ecological Studies 204. Springer, New York: 203-214.

Urbańska, M., W. Andrzejewski, H. Gierszal \& J. Golski, 2018. Are there any differences in the fouling of the native and invasive Unionidae by Dreissena polymorpha? Inland Waters. https://doi.org/10.1080/20442041.2018.1502985.

Urbańska, M., M. Kirschenstein, K. Obolewski \& M. Ożgo, 2019. Silent invasion: Sinanodonta woodiana successfully reproduces and possibly endangers native mussels in the north of its invasive range in Europe. International Review of Hydrobiology 104: 127-136. 
Ward, J. M. \& A. Ricciardi, 2007. Impacts of Dreissena invasions on benthic macroinvertebrate communities: a metaanalysis. Diversity and Distributions 13: 155-165.

Watters, G. T., 1997. A synthesis and review of the expanding range of the asian freshwater mussel Anodonta woodiana (Lea, 1834) (Bivalvia, Unionidae). The Veliger 40: 152-155.

Vidrine, M. F., 1996. North American Najadicola and Unionicola: Systematics and Coevolution. Gail Q, Vidrine Collectables, Eunice, LA, USA.

Vaughn, C. C., 2018. Ecosystem services provided by freshwater mussels. Hydrobiologia 810: 15-27.
Vaugh, C. C. \& D. E. Spooner, 2006. Scale-dependent association between native freshwater mussels and invasive Corbicula. Hydrobiologia 568: 331-339.

Yanovych, L. M., 2015. Reproductive features of indigenous and the invasive Chinese freshwater mussels (Mollusca, Bivalvia, Anodontinae) in Ukraine. Vestnik Zoologii 49: 433-438.

Publisher's Note Springer Nature remains neutral with regard to jurisdictional claims in published maps and institutional affiliations. 